\title{
UNDANG-UNDANG PEMERINTAHAN DAERAH NOMOR : 32 TAHUN 2004 DILIHAT DARI FUNGSI HUKUM "A TOOL OF SOCIAL ENGINEERING DAN A TOOL OF SOCIAL CONTROL" (Suatu Kajian Sosiologi Hukum)
}

\author{
Almaida Galung \\ Dosen Fakultas Hukum Universitas Widya Gama Samarinda
}

\begin{abstract}
ABSTRAK
Peranan a tool of social engineering dan a tool of social control terhadap Undangundang Pemerintahan Daerah Nomor : 32 Tahun 2004, sebagai sarana pengendalian sosial (a tool of social control) tetapi hukum juga berfungsi sebagai sarana rekayasa sosial (a tool of social engineering). Fungsi hukum inilah yang merupakan alat untuk menerapkan aturan hukum untuk diberlakukan kepada masyarakat sekaligus penerapannya kepada penguasa yang diberlakukan dari atas ke bawah tanpa adanya penolakan atas kehadirannya. Fungsi inilah yang mendasarinya betapa kuatnya pengaruh kelompok elit yang dapat memanfaatkan perubahan-perubahan yang diinginkan di dalam menyamakan persepsi atau pengaruhnya di dalam memanfaatkan kedudukan eksekutif mayoritas di parlemen.
\end{abstract}

Kata Kunci : Undang-Undang Nomor 32 Tahun 2004, Sarana Kontrol dan Rekayasa Sosial.

\section{PENDAHULUAN}

Dengan bergulirnya reformasi dengan begitu pesat menerobos kekuatan orde baru yang dikendalikan oleh Presiden Republik Indonesia yang ke-2 Presiden Soeharto yang begitu lama di dalam cengkraman sehingga perjalanan demokrasi yang diharapkan oleh rakyat Indonesia berjalan di tempat. Jatuhnya rezim orde baru membuka kesempatan yang besar baik bagi rakyatnya maupun pemerintah daerah yang ada diseluruh wilayah Republik Indonesia untuk mencari jati dirinya yang selama ini dikekang oleh Penguasa orde baru. Runtuhnya Uni Soviet oleh glasnot dan Prostika sehingga daerah-daerah yang berada di dalam Uni Soviet mendirikan negaranegara baru yang jauh dari ciri khas pada waktu masih di dalam kekuasaan Rezim komunis tersebut. Hal ini sama yang terjadi di dalam negara Yugoslavia banyak 
daerah mendirikan negara yang berpisah pada Biograd (ibu kota Yogoslavia) bahkan menimbulkan perang saudara yang berkepanjangan, perang Balkan antara Serbia dengan Bosnia beserta Kroasia.

Pemerintah Pusat di Jakarta mengkawatirkan hal tersebut terjadi di Indonesia dengan keanegaragaman yang berbeda-beda dengan bahasa yang berbeda begitu pula adat yang berbeda-beda pada setiap daerah-daerah. Keterbukaan Reformasi ini begitu deras sehingga setiap daerah, apalagi daerah yang mempunyai potensial kekayaan alam yang besar mempunyai keiginan untuk mendirikan negara sendiri. Pemerintah pusat menilai gejala ini sangat mungkin terjadi bergejolaknya daerah-daerah untuk berpikir sama, oleh sebab itu Pemerintah Pusat menciptakan dengan melihat fungsi hukum sebagai alat rekayasa sosial dan sebagai alat pengendali sosial di dalam menerapkan Undang-undang tentang Pemerintahan Daerah Nomor 32 Tahun 2004.

Bahwa Pemerintahan Pusat memberikan angin segar untuk sedikit memberikan kebebasan di dalam pengelolaan daerah dengan penggunaan anggaran belanja yang di anggap berimbang antara pusat dengan daerah, dengan menjauhkan kepada pembentukan angkatan bersenjata, bidang politik luar negeri, Hankam, Peradilan, Pembuatan mata uang dan berhubungan dengan perjanjian dengan negara lain.

Produk hukum undang-undang Otonomi Daerah Undang-undang Nomor 22 tahun 1999 memberikan lampu hijau yang mempunyai landasan hukum untuk memberikan arah dan semangat daerah-daerah di dalam pengelolaan daerah untuk lebih maju dan menumbuhkan prakarsa dan kreativitas mereka secara aktif untuk memprioritaskan ciri khusus yang melekat di daerahnya. Semangat inilah yang diharapkan untuk mempercepat pembangunan bangsa di segala sektor, keanegaragaman adat istiadat, bahasa, kebudayaan sebagai kekayaan natural yang dipertahankan oleh masing-masing daerah untuk saling melengkapi sehingga memberikan keutuhan yang sempurna dan melengkapi satu sama lain yang memberikan keutuhan bagi bangsa maupun negara.

Beberapa hal yang mendasar mengenai otonomi daerah dalam Undang-undang Nomor 22 Tahun 1999 tentang Pemerintahan Daerah yang sangat berbeda dengan prinsip undang-undang sebelumnya Undang-undang Nomor 5 Tahun 1974 yaitu :

1. Dalam Undang-undang Nomor 5 Tahun 1974 pelaksanaan otonomi daerah Iebih mengedepankan otonomi daerah sebagai kewajiban daripada hak, sedang dalam Undang-undang No:22 Tahun 1999 menekankan arti penting kewenangan daerah dalam mengatur dan mengurus kepentingan masyarakat melalui prakarsanya sendiri.

2. Prinsip yang menekankan asas desentralisasi dilaksanakan bersama-sama dengan asas dekonsentrasi seperti yang selama ini diatur dalam Undang-undang Nomor 5 Tahun 1974 tidak dipergunakan Iagi, karena kepada daerah otonom diberikan otonomi yang Iuas, nyata dan bertanggungjawab. HaI ini secara proporsional diwujudkan dengan pengaturan, pembagian dan pemanfaatan sumber daya nasional yang berkeadilan, serta perimbangan keuangan pusat dan daerah. Di 
samping itu, otonomi daerahjuga dilaksanakan dengan prinsip-prinsip demokrasi yang juga memperhatikan keanekaragaman daerah.

3. Beberapa hal yang sangat mendasar dalam penyelenggaraan otonomi daerah dalam Undang-undang Nomor 22 Tahun 1999, adalah pentingnya pemberdayaan masyarakat, menumbuhkan prakarsa dan kreativitas mereka secara aktif, serta meningkatkan peran dan fungsi Badan Perwakilan Rakyat Daerah. Oleh karena itu, dalam Undang-undang ini otonomi daerah diletakkan secara utuh pada daerah otonom yang lebih dekat dengan masyarakat, yaitu daerah yang selama ini berkedudukan sebagai Daerah Tk. II, yang dalam Undang-undang ini disebut Daerah Kabupaten dan Daerah Kota.

4. Sistem otonomi yang dianut dalam Undang-undang Nomor 22 Tahun 1999 adalah otonomi yang luas, nyata dan bertanggung jawab, dimana semua kewenangan pemerintah, kecuali bidang politik luar negeri, hankam, peradilan, moneter dan fiskal serta agama dan bidang- bidang tertentu diserahkan kepada daerah secara utuh, bulat dan menyeluruh, yang ditetapkan dengan peraturan pemerintah.

5. Daerah otonom mempunyai kewenangan dan kebebasan untuk membentuk dan melaksanakan kebijakan menurut prakarsa dan aspirasi masyarakat. Sedang yang selama ini disebut Daerah Tingkat I atau yang setingkat, diganti menjadi daerah propinsi dengan kedudukan sebagai daerah otonom yang sekaligus wilayah administrasi, yaitu wilayah kerja Gubernur dalam melaksanakan fungsi-fungsi kewenangan pusat yang didelegasikan kepadanya.

6. Kabupaten dan Kota sepenuhnya menggunakan asas desentralisasi atau otonom. Dalam hubungan ini, kecamatan tidak lagi berfungsi sebagai peringkat dekonsentrasi dan wilayah administrasi, tetapi menjadi perangkat daerah kabupaten/kota. Mengenai asas tugas pembantuan dapat diselenggarakan di daerah propinsi, kabupaten, kota dan desa. Pengaturan mengenai penyelenggaraan pemerintahan desa sepenuhnya diserahkan pada daerah masingmasing dengan mengacu pada pedoman yang ditetapkan oleh pemerintah.

7. Wilayah Propinsi meliputi wilayah laut sepanjang 12 mil dihitung secara lurus dari garis pangkal pantai, sedang wilayah Kabupaten/Kota yang berkenaan dengan wilayah laut sebatas $1 / 3$ wilayah laut propinsi.

8. Pemerintah Daerah terdiri dari Kepala Daerah dan perangkat daerah lainnya sedang DPRD bukan unsur pemerintah daerah. DPRD mempunyai fungsi pengawasan, anggaran dan legislasi daerah. Kepala daerah dipilih dan bertanggung jawab kepada DPRD. Gubernur selaku kepala wilayah administratif bertanggung jawab kepada Presiden. 
9. Peraturan Daerah ditetapkan oleh Kepala Daerah dengan persetujuan DPRD sesuai pedoman yang ditetapkan Pemerintah, dan tidak perlu disahkan oleh pejabat yang berwenang.

10. Daerah dibentuk berdasarkan pertimbangan kemampuan ekonomi, potensi daerah, sosial budaya, sosial politik, jumlah penduduk, luas daerah, dan pertimbangannya lain yang memungkinkan terselenggaranya otonomi daerah, daerah, daerah yang tidak mampu menyelenggarakan otonomi daerah dapat dihapus dan atau digabung dengan daerah lain. Daerah dapat dimekarkan menjadi lebih dari satu daerah, yang ditetapkan dengan undang-undang.

11. Setiap daerah hanya dapat memiliki seorang wakil kepala daerah, dan dipilih bersama pemilihan kepala daerah dalam satu paket pemilihan oleh DPRD.

12. Yang dapat menjadi Kepala Daerah adalah warga negara Republik Indonesia dengan syarat-syarat :

a) Bertakwa kepada Tuhan Yang Maha Esa.

b) Setia dan taat kepada Negara Kesatuan Republik Indonesia dan Pemerintah yang sah.

c) Tidak pernah terlibat dalam kegiatan yang mengkhianati Negara Kesatuan Republik Indonesia yang berdasarkan Pancasila dan UUD 1945 yang dinyatakan dengan surat keterangan Ketua Pengadilan Negeri.

d) Berpendidikan sekurang-kurangnya SLTA dan atau sederajat.

e) Berumur sekurang-kurangnya 30 tahun.

f) Sehat jasmani dan rohani.

g) Nyata-nyata tidak terganggu jiwa/ingatannya.

h) Tidak pernah dihukum penjara karena melakukan tindak pidana.

i) Tidak sedang dicabut hak pilihnya berdasarkan keputusan pengadilan negeri.

j) Mengenal daerahnya dan dikenal oleh masyarakat daerahnya.

k) Menyerahkan daftar kekayaan pribadi.

1) Bersedia dicalonkan menjadi Kepala Daerah. 
13. Daerah diberi kewenangan untuk melakukan pengangkatan, pemindahan, pemberhentian, penetapan pensiun, pendidikan dan pelatihan pegawai sesuai dengan kebutuhan dan kemampuan daerah, berdasarkan nama, standar, prosedur yang ditetapkan pemerintah.

14. Keuangan daerah bersumber dari pendapatan asli daerah, dana perimbangan keuangan pusat dan daerah, pinjaman daerah dan lain-lain pendapatan sah. Dalam setiap kewenangan pemerintahan yang menjadi wewenang daerah melekat kewenangan keuangan.

15. Kepada Kabupaten dan Kota diberikan otonomi yang luas, sedang pada propinsi otonomi yang terbatas. Kewenangan yang ada pada propinsi adalah otonomi yang bersifat lintas Kabupaten dan Kota, yakni serangkaian kewenangan yang tidak efektif dan efisien kalau diselenggarakan dengan pola kerjasama antar Kabupaten atau Kota. Misalnya kewenangan di bidang perhubungan, pekerjaan umum, kehutanan dan perkebunan dan kewenangan bidang pemerintahan tertentu lainnya dalam skala propinsi termasuk berbagai kewenangan yang belum mampu ditangani Kabupaten dan Kota.

16. Pengelolaan kawasan perkotaan di luar daerah kota dapat dilakukan dengan cara membentuk badan pengelola tersendiri, baik secara intern oleh pemerintah Kabupaten sendiri maupun melalui berkerjasama antar daerah atau dengan pihak ketiga. Selain DPRD, daerah juga memiliki kelembagaan lingkup pemerintah daerah, yang terdiri dari Kepala Daerah, Sekretariat Daerah, Dinas-Dinas Tehnis Daerah, Lembaga Staf Teknis Daerah, seperti yang menangani perencanaan, penelitian dan pengembangan, pendidikan dan latihan, pengawasan dan badan usaha milik daerah. Besaran dan pembentukan lembaga-lembaga itu sepenuhnya diserahkan pada daerah. Lembaga pembantu Gubernur, Pembantu Bupati/Walikota, Asisten Sekwilda, Kantor Wilayah dan Kandep dihapus.

17. Kepala Daerah sepenuhnya bertanggungjawab kepada DPRD, dan DPRD dapat meminta Kepala Daerahnya berhenti apabila pertanggung jawaban Kepala daerah setelah 2 (dua) kali tidak dapat diterima oleh DPRD.

Bahwa kemajuan Undang-undang No. 22 tahun 1999 sangat luar biasa di dalam mengembangkan sepenuhnya kepada Daerah-daerah secara optimal sebagai bentuk sebagai sarana pengendalian sosial (a tool of social control) tetapi hukum juga berfungsi sebagai sarana rekayasa sosial (a tool of social engineering).

Pada tanggal 29 September 2004 DPR-RI dan Presiden-RI telah menyetujui bersama Rancangan Undang Undang Tentang Pemerintahan Daerah untuk disahkan menjadi Undang Undang Undang-Undang Nomor 32 tahun 2004.

Lahirnya Undang Undang Nomor 32 Tahun 2004 tentang Pemerintahan Daerah sebagai pengganti Undang Undang Nomor 22 Tahun 1999 tentang Pemerintahan Daerah, diharapkan dapat menyelesaikan berbagai permasalahan yang timbul 
dibidang penyelenggaraan Pemerintahan Daerah sebagai akibat berlakunya UndangUndang Nomor 22 Tahun 1999 tentang Pemerintahan Daerah yang mulai berlaku sejak tanggal 19 Nopember 1999.

Salah satu dorongan yang sangat penting untuk melakukan perubahan terhadap beberapa ketentuan dalam Undang Undang Nomor 22 Tahun 1999, antara lain adalah untuk meluruskan kembali pemahaman penerapan sistem desentralisasi atau daerah otonom, tanpa mengesampingkan pemahaman bahwa sistem ketatanegaraan yang dianut oleh Republik Indonesia adalah Negara Kesatuan .

Penegasan bentuk Negara Republik Indonesia adalah Negara Kesatuan dengan jelas dapat kita baca dalam Pasal 1 ayat (1) Undang Undang Dasar Tahun 1945 baik sebelum maupun beberapa kali perubahan.

Penerapan Undang Undang Nomor 22 Tahun 1999 Tentang Pemerintahan Daerah telah menimbulkan berbagai permasalahan dalam penyelenggaraan pemerintahan daerah. Keadaan yang demikian apabila tidak segera diambil langkahlangkah penanggulangannya, dikhawatirkan dapat membahayakan eksistensi atau kelangsungan Negara Kesatuan Republik Indonesia.

\section{PERMASALAHAN}

Dari uraian latar belakang tersebut di atas, rumusan masalah yang diajukan dalam tulisan ini adalah :

1) Bagaimana Fungsi Hukum sebagai sarana pengendalian sosial (a tool of social control) dan hukum juga berfungsi sebagai sarana rekayasa sosial (a tool of social engineering) atas perubahan Undang Undang Nomor 22 Tahun 1999 menjadi Undang-undang Nomor : 32 Tahun 2004 tentang pemerintahan Daerah ?

Memperhatikan perumusan masalah sebagaimana tersebut di atas, maka penelitian ini bertujuan untuk:

1. Mengkaji hubungan Fungsi Hukum sebagai sarana pengendalian sosial (a tool of social control) dan hukum juga berfungsi sebagai sarana rekayasa sosial (a tool of social engineering) atas perubahan Undang Undang Nomor 22 Tahun 1999 menjadi Undang-undang Nomor : 32 Tahun 2004 tentang pemerintahan Daerah.

Hasil penelitian ini diharapkan sebagai salah satu sumbangan pemikiran untuk kepentingan masyarakat dan pemerintah daerah maupun pusat, baik secara teoritis maupun praktis yaitu :

1. Secara teoritis, yaitu untuk kepentingan ilmiah sebagai in-put bagi Fungsi Hukum sebagai sarana pengendalian sosial (a tool of social control) dan hukum juga berfungsi sebagai sarana rekayasa sosial (a tool of social engineering) atas perubahan Undang Undang Nomor 22 Tahun 1999 menjadi Undang-undang Nomor : 32 Tahun 2004 tentang pemerintahan Daerah 
2. Secara praktis yaitu memberikan sumbangan pemikiran dalam rangka pelaksanaan produk hukum yang didukung oleh fungsi hukum sebagai sarana pengendalian sosial (a tool of social control) dan hukum juga berfungsi sebagai sarana rekayasa sosial (a tool of social engineering) atas perubahan Undang Undang.

\section{METODE PENELITIAN}

Penelitian ini menggunakan pendekatan Yuridis empiris, Pendekatan Yuridis empiris yang dimaksud untuk menulusuri peranan fungsi hukum sebagai sarana pengendalian sosial (a tool of social control) dan hukum juga berfungsi sebagai sarana rekayasa sosial (a tool of social engineering) atas perubahan Undang Undang.

\section{A. Jenis Penelitian}

Jenis penelitian ini deskriptif analisis, yaitu menggambarkan secara tuntas terhadap fungsi hukum sebagai sarana pengendalian sosial (a tool of social control) dan hukum juga berfungsi sebagai sarana rekayasa sosial (a tool of social engineering) atas perubahan Undang Undang.

\section{B. Sumber Data}

Sumber data dalam penelitian ini menggunakan data primer dan data sekunder. Data primer menyangkut pemberlakuan Undang-undang No. 32 tahun 2004 sampai saat ini atas daerah-daerah. Data sekunder mencakup bahan-bahan hukum primer dan Undang-undang No.22 tahun 1999.

\section{PEMBAHASAN}

Menurut Roscoe Pound \& Carl Von Savigny yang terkenal dengan teorinya Bahwa adalah alat yang mempengaruhi merekayasa masyarakat (a tool of social engineering), jadi apa yang dilakukan pembentukan hukum adalah penyimbangan segala kepentingan yang ada dalam masyarakat dan pemerintah. Kepentingan negara harus paling tinggi atas karenanya mempunyai kepentingan nasional. Kepentingan nasional tersebut harus melindungi kepentingan negara kemauan negara adalah kemauan publik.

Hukum ituberperan untuk merubah keadaan masyarakat seperti apa yang diinginkan oleh hukum. Hukum dapat melakukan perubahan secara paksa, agar dapat dapat yang diinginkan oleh hukum, hukum dipaksakan ke bawah, contoh Pemerintah melarang merokok, berhenti merokok adalah kepentingan masyarakat. Jika Negara 
memaksa kita untuk merobah atau melarang kita menjadi lebih baik. Karena merokok dapat merugikan kesehatan.inilah yang disebut Social Control.

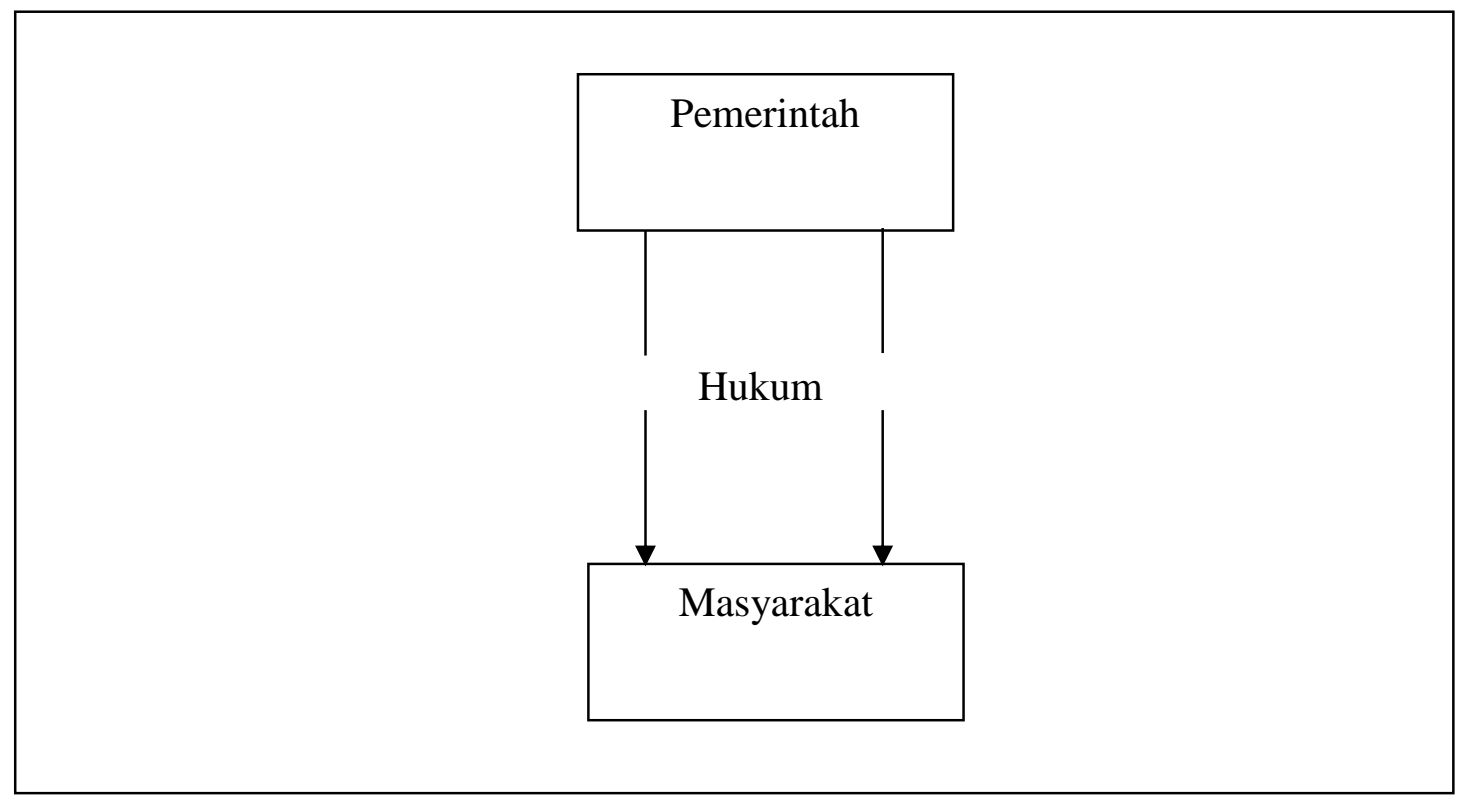

Dalam proses pembentukan paraturan hukum oleh istitusi politik, peranan kekuatan politik hukum itu sangat menentukan. Institusi politik secara resmi diberikan otoritas untuk membentuk hukum hanyalah sebuah institusi yang vacum tanpa diisi oleh mereka yang diberi kewenangan untuk itu.

Pertentangan Fungsi Hukum sebagai sarana pengendalian sosial (a tool of social control) dan hukum juga berfungsi sebagai sarana rekayasa sosial (a tool of social engineering) atas perubahan Undang Undang, atas hukum berasal dari masyarakat yang diwakilkan oleh Legislatif sebagai DPR wakil rakyat di dalam pemerintahan. Apa yang diinginkan masyarakat akan diaspirasikan di dalam pembuatan Undang-undang.

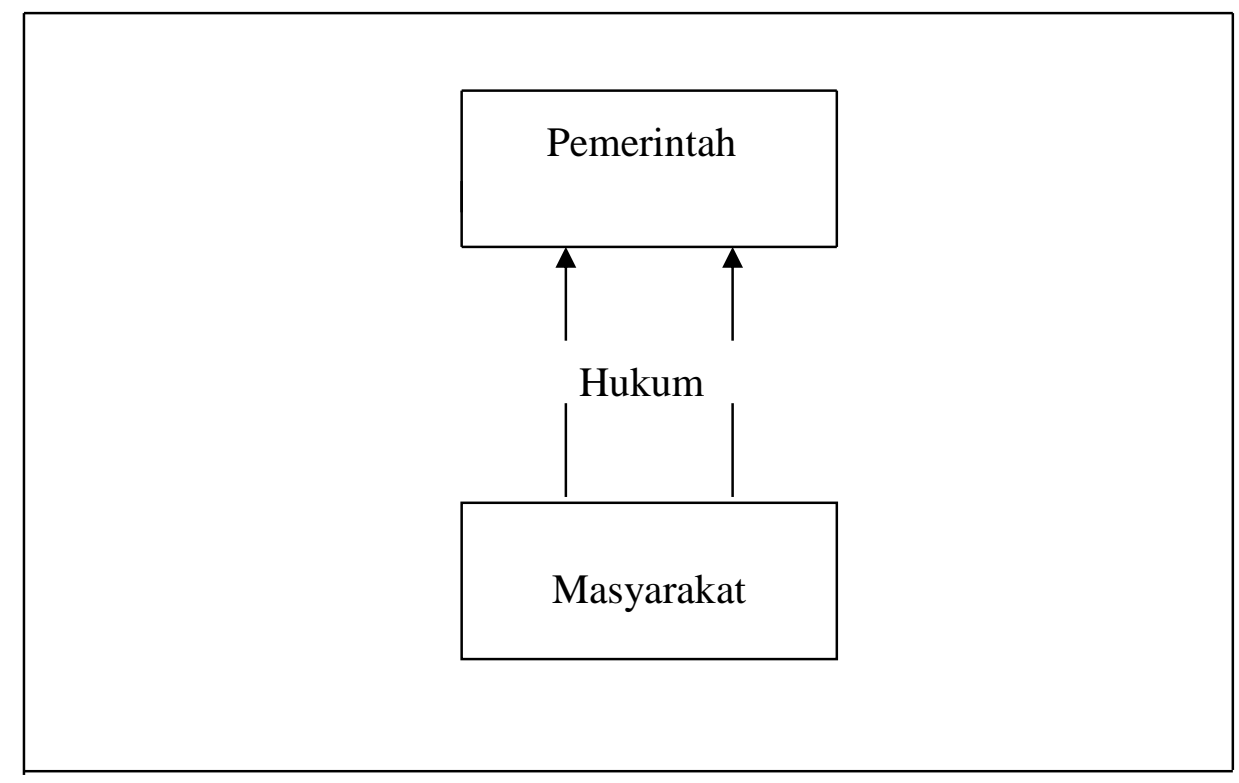


Proses pembentukan hukum di Indonesia selalu dipengaruhi oleh suatu kepentingan-kepentingan. Kekuasaan politiklah yang memiliki kepentingan tersebut. Kekuasaan politik tersebut duduk di dalam institusi untuk melakukan legislasi kepentingan.

Pembentukan undang-undang secara komprehensif perlu memperhatikan 3 (tiga) dimensi, yaitu masa lalu yang terkait dengan sejarah perjuangan bangsa, masa kini yaitu kondisi objektif yang ada sekarang dengan lingkungan strategisnya dengan memandang ke masa depan yang dicita-citakan. Dalam kaitan itu, maka dalam penyusunan program pembentukan undang-undang perlu mempertimbangkan heterogenitas hukum yang terdiri dari hukum adat, hukum Islam, hukum agama lainnya, hukum kontemporer, serta Pancasila dan Undang-Undang Dasar Negara Republik Indonesia Tahun 1945 sebagai sumber hukum tertinggi.

Di samping itu, dalam pembentukan undang-undang perlu dipegang teguh 3 (tiga) prinsip, yaitu:

1. kesetiaan kepada cita-cita Sumpah Pemuda, proklamasi kemerdekaan 17 Agustus, serta nilai-nilai filosofis yang terkandung dalam Pancasila, serta nilai-nilai konstitusional sebagaimana termaktub dalam Undang-Undang Dasar Negara Republik Indonesia Tahun 1945;

2. terselenggaranya negara hukum Indonesia yang demokratis, adil, sejahtera, dan damai; dan

3. Dikembangkannya norma-norma hukum dan pranata hukum baru dalam rangka mendukung dan melandasi masyarakat secara berkelanjutan, tertib, lancar, dan damai serta mengayomi seluruh tumpah darah dan segenap bangsa Indonesia .

Beberapa Perubahan Yang Signifikan Ketentuan Tentang Pemerintahan Daerah Dalam Undang Undang Nomor 32 Tahun 2004 tentang Pemerintahan Daerah. Sebelumnya permasalahan yang timbul sebagai akibat berlakunya Undang Undang Nomor 22 Tahun 1999 antara lain ;

1. Seolah terputus hubungan secara hirarki dan administrasi antara Pemerintah Pusat dan Pemerintah Daerah Provinsi, Daerah Kabupaten, dan Daerah Kota, antara lain sebagai akibat ketentuan dalam Pasal 4 ayat (2) Undang Undang Nomor 22 Tahun1999 tentang Pemerintahan Daerah.

2. Timbul gap yang mencolok mengenai kesejahteraan masyarakat antara daerah yang surplus dan daerah yang minus.

3. Timbul kerancuan dalam pengelolaan sumber daya alam antara kewenangan Pemerintah Pusat dan Pemerintah Daerah dan dikhawatirkan dapat mengancam keutuhan wilayah Negara Kesatuan Republik Indonesia. Hal tersebut sebagai akibat ketentuan yang rancu 
dalam Pasal 10 Undang Undang Nomor 22 Tahun1999 tentang Pemerintahan daerah.

4. Terdapat gejala atau usaha dari beberapa daerah yang ingin memisahkan diri dari Negara Kesatuan Republik Indonesia. Di sisi lain sistem Negara Kesatuan sudah dengan penuh pengorbanan diperjuangkan oleh para pendiri Negara Republik Indonesia.

5. Timbulnya permasalahan di bidang penerapan peraturan perundangundangan antara Pemerintah Pusat dan Pemerintah daerah, sebagai akibat adanya ketentuan dalam Tap MPR Nomor III/MPR/2000, yang dalam hierarki Peraturan Perundang-undangan tidak mencantumkan Peraturan yang dikeluarkan oleh Menteri. Beberapa daerah menolak penerapan Peraturan Menteri, sedangkan sesuai dengan ketentuan Pasal 7 Undang Undang Nomor 22 Tahun 1999 tidak semua kewenangan Pemerintah Pusat diserahkan kepada Pemerintah Daerah.

Dalam tulisan ini pula dicoba untuk mengkritisi terhadap beberapa ketentuan dalam Undang Undang Nomor 32 Tahun 2004 tentang Pemerintahan Daerah yang selain merupakan penyempurnaan secara signifikan terhadap ketentuan dalam Undang-Undang Nomor 22 Tahun 1999 tentang Pemerintahan Daerah juga menampung berbagai perkembangan kebutuhan hukum dalam masyarakat yang sebenarnya kurang tepat jika pengaturannya dijadikan satu dengan pengaturan tentang penyelenggaraan Pemerintahan Daerah. Beberapa ketentuan yang signifikan Ketentuan Undang Undang Nomor 22 Tahun 1999 Yang Diatur Dalam Undang Undang Nomor 32 Tahun 2004 tentang Pemerintahan Daerah.

Dikatakan mengkritisi "beberapa ketentuan" karena dengan keterbatasan waktu yang diberikan, sulit untuk dapat mencermati seluruh ketentuan dalam UndangUndang Nomor 32 Tahun 2004 yang berjumlah 240 (dua ratus empat puluh) pasal tersebut.

Selanjutnya, karena Undang Undang Nomor 32 Tahun 2004 sifatnya juga menampung perkembangan kebutuhan pengaturan yang sebenarnya tidak tepat bila diatur menjadi satu dalam Undang-Undang tentang Pemerintahan Daerah, maka bila kita cermati terdapat kejanggalan mengenai substansi yang diatur dalam UndangUndang Nomor 32 Tahun 2004.

Kejanggalan tersebut antara lain pengaturan mengenai Komisi Pemilihan Umum Daerah, Panitia Pemilihan, Panitia Pemungutan Suara, dan Kampanye Pemilihan, yang juga menjadi materi dari Undang Undang Nomor 32 Tahun 2004.

Dikatakan kejanggalan, karena dalam Teknik Penyusunan Peraturan Perundang-undangan, judul suatu peraturan harus mencerminkan substansi yang diatur. Oleh karena itu, substansi yang diatur dalam Undang Undang Nomor 32 Tahun 2004 sesuai dengan judulnya, haruslah yang terkait langsung mengenai PemerintahanDaerah.

Beberapa ketentuan dalam Undang Undang Nomor 32 Tahun 2004, juga masih menimbulkan ketidakpastian hukum dalam penerapannya, antara lain ketentuan yang diatur dalam Pasal 16 ayat (3), Pasal 17 ayat (3), dan Pasal 18 ayat (7), karena 
pendelegasian pengaturan lebih lanjut dalam pasal-pasal tersebut tidak disebut secara jelas instrument hukum yang digunakan, misalnya Peraturan Pemerintah ataukah Peraturan Presiden. Rumusan yang digunakan adalah dengan "Peraturan Perundangundangan" sedangkan peraturan perundang-undangan banyak jenisnya.

Ketentuan dalam Undang Undang Nomor 32 Tahun 2004 yang berhasil dicermati antara lain :

1. Terdapat sistematika yang tidak tepat meletakkannya atau merumuskannya, yakni pada BAB IV Bagian Kedelapan Paragraf Ketujuh, yang menyatakan tentang "Ketentuan Pidana Pemilihan Kepala Daerah dan Wakil kepala Daerah". Cara penulisan dan peletakan ketentuan pidana yang demikian tidak lazim dalam Teknik Penyusunan Peraturan Perundang-undangan. Ketentuan Pidana seharusnya diletakkan sebelum BAB tentang Ketentuan Peralihan. Apabila Ketentuan Peralihan tidak ada, letak Ketentuan Pidana sebelum BAB Ketentuan Penutup dengan judul KETENTUAN PIDANA, tanpa menyebut objeknya.

2. Terdapat beberapa rumusan norma yang tidak jelas sehingga sulit dalam penerapannya, misalnya :

Ketentuan Pasal 216 ayat (2) disebutkan bahwa: Perda, sebagaimana dimaksud pada ayat (1) wajib mengakui dan menghormati... dan seterusnya. Perda adalah benda mati apakah bisa mengakui dan menghormati ?

Ketentuan Pasal 219 ayat (1) disebutkan bahwa : Pemerintah memberikan penghargaan dalam penyelenggaraan Pemerintahan Daerah. Ketentuan dalam Pasal tersebut tanpa diikuti pernyataan lebih lanjut mengenai berbagaihal yang terkait dengan "pemberian penghargaan" misalnya dalam bidang apa, bagaimana persyaratannya, apa kriterianya, serta dalam bentuk apa penghargaan diberikan. Ketentuan seperti Pasal 219 ayat (1) adalah Pasal mandul yang sulit dalam pelaksanaannya.

Ketentuan Pasal 220 Ketentuan dalam Pasal 220 inipun merupakan Pasal yang mandul dan sama sekali tidak memperhatikan Teknik Penyusunan Peraturan Perundang-undangan. Dalam Teknik Penyusunan Peraturan Perundangundangan, dalam hal merumuskan sanksi maka harus jelas berupa sanksi pidana, perdata, atau sanksi administratif. Selanjutnya dalam hal sanksi administratif pun, harus dirumuskan secara tegas dan rinci apa bentuk dari sanksi administratif tersebut.

3. Definisi/batasan pengertian Dalam Undang Undang Nomor 32 Tahun 2004 tidak hanya substansi dalam batang tubuh Undang Undang Nomor 22 Tahun 1999 yang dilakukan penyempurnaan, tetapi juga mencakup definisi/batasan pengertian. Penyempurnaan terhadap definisi/batasan pengertian sangat penting karena definisi/batasan pengertian merupakan peletak dasar pemahaman atas norma/substansi yang diatur dalam Bab berikutnya. Penyempurnaan yang sangat signifikan antara lain mengenai definisi tentang :

a. Pemerintahan Daerah Dalam Undang Undang Nomor 32 Tahun 2004 mengenai definisi "Pemerintahan Daerah" dibuat penegasan "dalam sistim 
dan prinsip Negara Kesatuan Republik Indonesia sebagaimana dimaksud dalam Undang Undang Dasar Negara Republik Indonesia Tahun 1945”.

b. Penegasan tersebut mempunyai makna yang sangat signifikan untuk lebih menegaskan bahwa penyelenggaraan pemerintahan oleh Pemerintah daerah tidak terlepas dari ikatan hirarki dan hubungan administrasi dengan Pemerintah Pusat atau dengan Pemerintah Daerah lainnya.

Dalam Undang Undang Nomor 22 Tahun 1999 penegasan "dalam ikatan Negara Kesatuan Republik Indonesia" dapat dijumpai pada definisi "Daerah Otonom" dan "Desentralisasi". Penegasan tersebut dicantumkan juga dalam definisi "Daerah Otonom" dan "Desentralisasi" dalam Undang Undang Nomor 32 Tahun 2004, walaupun dengan rumusan yang berbeda.

Dalam Undang Undang Nomor 22 Tahun 1999 digunakan frasa secara tidak konsisten, yakni "dalam kerangka Negara Kesatuan Republik Indonesia"(dalam definisi Desentralisasi) dan "dalam ikatan Negara Kesatuan Republik Indonesia" (dalam definisi "Daearah Otonom").

Dalam Undang Undang Nomor 32 Tahun 2004 frasa yang digunakan sudah konsisten, karena menggunakan frasa yang sama yakni "dalam sistim Negara Kesatuan Republik Indonesia".

c. Otonomi Daerah Dalam Undang Undang Nomor 22 Tahun 1999 "Otonomi Daerah" didefinisikan sebagai kewenangan untuk mengatur dan mengurus kepentingan masyarakat setempat menurut prakarsa sendiri. Dan seterusnya. Dalam Undang Undang Nomor 32 Tahun 2004 pengertian "Otonomi Daerah" dikembalikan secara proporsional dalam konteks Negara Kesatuan dengan menghilangkan frasa "menurut prakarsa sendiri" dan diganti dengan rumusan "mengatur dan mengurus sendiri urusan Pemerintah dan kepentingan masyarakat setempat sesuai dengan peraturan perundang-undangan". Walaupun sama-sama menggunakan kata "sendiri" namun dalam konteks keseluruhan frasa, antara kedua rumusan tersebut mempunyai makna yang sangat berbeda.

d. Tugas Pembantuan Definisi "Tugas Pembantuan" dilakukan penyederhanaan tanpa menyebutkan "disertai pembiayaan, sarana dan prasarana serta sumber daya manusia. dan seterusnya, tetapi lebih ditekankan pada ketentuan siapa yang memberikan tugas dan siapa yang diberi tugas". Definisi yang demikian lebih tepat, karena beda antara merumuskan definisi dan norma.

Posisi Hubungan Pemerintah Pusat dan Pemerintah Daerah Pasal 4 ayat (2) Undang Undang Nomor 22 Tahun 1999 menentukan bahwa daerah sebagaimana dimaksud pada ayat (1) artinya Provinsi, Kabupaten, atau Kota masing-masing berdiri sendiri dan tidak mempunyai hubungan hirarki satu sama lain.

Ketentuan dalam Pasal 4 ayat (2) inilah yang dalam perjalanan sejarah penerapan Undang Undang Nomor 22 Tahun 1999 banyak menimbulkan permasalahan, bahkan timbul kesenjangan atau konflik dalam penyelenggaraan 
pemerintahan baik antara Pemerintah Pusat dengan Pemerintah Daerah maupun antara Pemerintah Daerah Provinsi dengan Pemerintah Daerah Kabupaten/Kota.

Ketentuan Pasal 4 ayat (2) ini mengakibatkan pula berbagai permasalahan dalam menegakkan peraturan perundang-undangan tingkat pusat yang tidak secara tegas terdapat dalam hirarki peraturan perundang-undangan sebagaimana ditetapkan dalam Tap MPR Nomor III/MPR/2000.

Ketentuan dalam Pasal 4 ayat (2) Undang Undang Nomor 22 Tahun 1999 tersebut dalam Undang Undang Nomor 32 Tahun 2004 dilakukan perubahan secara mendasar yang dirumuskan dalam Pasal 2 ayat (4), ayat (5), ayat (6) danayat (7). Ketentuan dalam Pasal 2 ayat (4) menegaskan bahwa "PemerintahDaerah" dalam menyelenggarakan urusan pemerintahan memiliki hubungan dengan Pemerintah dan dengan Pemerintah Daerah lainnya.

Ayat (5) menegaskan "hubungan sebagaimana dimaksud pada ayat (4) meliputi hubungan wewenang keuangan, pelayanan umum, pemanfaatan sumber daya alam, dan sumber daya lainnya. Ketentuan dalam Pasal 2 Undang Undang Nomor 32 Tahun 2004 tersebut dimaksudkan untuk menghilangkan polemik pemahaman bahwa tidak ada hubungan secara hirarki antara Pemerintah Pusat dengan Pemerintah Daerah atau antara Pemerintah Daerah yang satu dengan Pemerintah daerah yanglainnya.

Bergulirnya penulisan ini adalah undang-undang tentang Pemerintahan daerah Nomor : 32 Tahun 2004 dilihat dari fungsi hukum sebagai "a tool of social engineering dan a tool of control". Objek dari Implementasi Undang- undang nomor 32 Tahun 2004 terhadap kehidupan umumnya masyarakat maupun khususnya terhadap pemerintahan yang ada di pusat maupun daerah dilihat dari. Hal dapat pula dapat dikatakan Apakah undang-undang ini sebagai alat rekayasa sosial dari tingkat atas ke bawah dan ataukah sebagai alat pengendalian social yang bersifat aktif

Sebagai negara yang terpusat pemerintahannya yang berwujud kekuasaan negara fungsi hukum sebagai "a tool of social engineering dan a tool of social control". Adalah merupakan sesuatu yang serasi antara teori dan penerapan prakteknya atau pula dapat disebut antara das Sollen dan das Sain adalah sama.

Fungsi hukum ini merupakan suatu fenomena yang juga merupakan fungsi yang ingin dicapai berdasarkan "a tool of social engineering dan a tool of control", yang juga merupakan fungsi yang tidak langsung ini, memperkuat atau memperlemah kecenderungan untuk menghargai nilai-nilai moral tertentu seperti mempengaruhi perasaan kesatuan social, memperkuat atau memperlemah penghargaan terhadap otoritas umum, kesucian hidup (the sanctity of life). Konsep hukum sebagai " a tool of Social engeneering" selama ini dianggap sebagai suatu konsep yang "netral" yang dicetuskan oleh Rescoe Pound. Konsep ini bisa dihadapkan dengan konsep hukum yang lain antaranya konsep aliran Historis dan frienderich Karl von Savigny.

Dengan berlakunya Undang-Undang Nomor : 32 tahun 2004 ini tentang pemerintahan daerah merupakan fungsi hukum sebagai alat rekayasa social dan atau pengendalian social di dalam Negara Kesatuan Republik Indonesia sangatlah tepat, apalagi berdasarkan UUD Negara RI tahun 1945 yang tertuang di dalam Pasal 18 Perubahan/amandemen P/A yang terakhir (10 Agustus 2002). Kecendrungan Prinsip 
Sentralisasi yang menggambarkan Jakarta adalah Pusat segala kegiatan di dalam yang ada di dalam UU Tentang Pemerintahan Daerah yaitu :

a) UU Otonomi No. 01 Tahun 1945.

b) UU Otonomi No. 22 Tahun 1948.

c) UU Otonomi No. 01 Tahun 1957.

d) UU Otonomi No.18 Tahun 1965.

e) UU Pokok Tentang Pemerintahan di Daerah yaitu; (UU Otonomi No. 05 Tahun 1974, UU Otonomi No. 22 Tahun 1999, UU Otonomi No. 32 Tahun 2004). Bahwa perubahan UU Otonomi Daerah yang terjadi di Negara kita merupakan fenomena Sosiologo Hukum yang sangat menarik untuk dibahas bersama.

Daya paksa pemerintah pusat tercermin pada Undang-undang ini keabsahannya adalah sah-sah saja apalagi didukung dengan suatu Konstitusi Negara yaitu Undang-undang dasar 1945, telah di ada perubahan/amandeman sebanyak 4 (empat) kali di Republik Indonesia sebagai dasar Hukum lahirnya dari semua Undang-undang atau peraturan-peraturan lain dibawahnya. Sebagaimana dengan UU No. 10 tahun 2004 Tentang Pembentukan Peraturan Perundang-undangan pada pasal 7 hierarki peraturan perundang-undangan menetapkan UU Dasar 1945 sebagai pada penempatan pertama pada susunan peraturan yang paling tinggi.

Melihat produk undang-undang sebelumnya Undang-undang Nomor 22 tahun 1999 tentang Otonomi Daerah yang pada prinsipnya bertentangan dengan UndangUndang Nomor 32 tahun 2004, Apakah hal ini mencerminkan bekerjanya fungsi hukum sebagai "a tool of social engineering dan a tool of social control". Hanya merupakan nampak negatif maupun positif sebagai fungsi hukum sebagai alat rekayasa social dan kontrol social yang memberikan keuntungan pada "The ruling class" tertentu atau suatu "Elite" tertentu dan justru bisa merugikan sebagaian besar warga masyarakat pada daerah tertentu maupun membawa dampak positif pada daerah lain tertentu pula.

Pada "Elite" dengan alat paksanya dengan penerapan undang-undang atau peraturan-peraturan di bawahnya dengan persetujuan Dewan Perwakilan Rakyatnya dapat menerapkan sesuatu perubahan-perubahan sebagai "a tool of social engineering dan a tool of social control", tanpa mendasarkan apa yang disebut jiwa dari pada semangat pembangunan pada masyarakat di daerah-daerah tertentu dengan alasanalasan tertentu pula bahkan melemahkan semangat spritnya yang telah tumbuh dengan tetap pada NKRI. Hilangnya kontrol daerah dianggap sebaga instabilitas dari pada penghianatan dari pada semangat perjuangan nasionalisme yang berlebihan.

Fungsi hukum sebagai rekayasa sosial adalah bahwa terjadinya perobahan social tidak mungkin semata-mata dilakukan oleh hukum, sehingga melihat peranan hukum sebagai perubahan social hendaklah dilihat sebagai sudut kemampuan hukum "initial push" terjadinya perubahan sosial melalui suatu proses yang cukup kompleks serta tidak merupakan hasil hubungan langsung antara suatu faktor tertentu dengan suatu kejadian.

Fungsi hukum dalam mencapai tujuannya, hukum harus difungsikan menurut fungsi-fungsi tertentu, dengan pemikiran tergantung dengan pada keinginan 
tercapainya sesuatu tujuan "The ruling class" tertentu atau suatu "Elite" dengan perwujudan UU Otonomi Daerah No. 32 tahun 2004.

Dengan bekerjanya fungsi hukum sebagai "a tool of social engineering dan a tool of social control". Semata - mata melegalkan keinginannya "Elite" yaitu membatasi kewenangan daerah yang lebih jauh setelah lahirnya UU Otonomi Daerah No. 22 tahun 1999 dengan membuat UU Otonomi Daerah No. 32 tahun 2004.

UU Otonomi Daerah No. 22 tahun 1999 merupakan produk undang-undang yang memberikan kewenangan yang lebih di bandingkan dengan produk UU yang telah lahir sebelumnya maupun setelahnya, yaitu khususnya memberikan kewenangan pada Kota dan Kabupaten untuk mengurus sesuatunya yang menurutnya lebih baik.

Daya paksa dari atas ke bawah sesuai dengan keinginan "Elite" dangan segala legalitasnya adalah sah-sah saja, akan tetapi hal ini sangat bertentangan roh dan jiwa semangat yang ada di daerah untuk bekerja dan bergerak sesuai dengan kemampuannya untuk mengembangkan potensi yang dimiliki menjadi terbatas yang ada terutama kemampuan "keuangan". Pembatasan ini ditambah lagi ketergantungannya pada pemerintah pusat menambah kekecewaan yang bisa menciptakan ketidakpercayaan daerah pada pusat.

Sehingga fungsi hukum sebagai "a tool of social engineering dan a tool of social control". Telah bekerja sebagaimana mestinya tergantung dari pada keinginan DPR dan Pemerintahan Pusat yaitu membuat undang-undang lahir dari suatu rekayasa dari atas dan juga sekaligus merupakan kontrol social pada daerah-daerah.

\section{KESIMPULAN}

Dari uraian di atas sebagai penutup Penulis mencoba menarik suatu kesimpulan yaitu :

A. Dengan bekerja fungsi hukum sebagai "a tool of social engineering dan a tool of social control". Sebagai alat rekayasa social maupun control social adalah sah-sah saja sebagai alat paksa dari atas ke bawah.

B. Dengan tetap berpatokan pada UU Dasar 1945 sebagai Konstitusi Negara sebagai landasar pijakan lahirnya UU, maka fungsi hukum sebagai "a tool of social engineering dan a tool of social contol". Tetap dapat digunakan tergantung dari pada keinginan perubahan yang di inginkan.

C. Hasil kerja dari fungsi hukum sebagai "a tool of social engineering dan a tool of social control". Sebenarnya tergantung Pemerintah Pusat sebagai "Good Governance" yang diberikan kepada daerah-daerah. 


\section{DAFTAR PUSTAKA}

Ali, Achmad, 1990 Belantara Hukum, Laphas, Ujung Pandang

Hariningsih, Sri, 2008 Mengkritisi Beberapa Perubahan Yang Signifikan

Kameo, Daniel, D., 2003 Otonomi Daerah Perkembangan Pemikiran Pengaturan dan Pelaksana.

Kaho, Josef Riwu, 2005 Prospek Otonomi Daerah di Negara Republik Indonesia.

Muljadi, Arief, 2005 Landasan dan Prinsip Hukum Otononmi Daerah dalam kesatuan RI.

Sedarmayanti, 2003 Good Governance,Penerbit CV. Mandar Maju.

Yuriadi, Agung, 2008 Perbandingan Teori Hukum menurut Roscoe Pound dan Friedrich Karl Von Savigny dipandang dari Perspektif Politik Hukum.

Undang-Undang Nomor 5 Tahun 1974 tentang Pemerintahan Daerah.

Undang-Undang Nomor 22 Tahun 1999 tentang Pemerintahan Daerah.

Undang-Undang Nomor 32 Tahun 2004 tentang Pemerintahan Daerah. 